\title{
Economic Use of Brewer's Dried Grain (BDG) in the Diet of Swine
}

\author{
T.B. Rijal ${ }^{1}$, D.B. Nepali ${ }^{2}$, R. A. Sah ${ }^{2}$ and M.P. Sharma ${ }^{2}$ \\ ${ }^{1}$ District Livestock Service Office, Chitwan \\ ${ }^{2}$ Institute of Agriculture and Animal Science, Rampur
}

\begin{abstract}
An experiment was conducted from $18^{\text {th }}$ October, 2006 to $18^{\text {th }}$ January, 2007 at IAAS Livestock Farm, Rampur, Chitwan to determine the substitution effects of soybean meal with brewer's dried grain (BDG) on the performance, economics and meat traits of swine production. Starter, grower and finisher diets were formulated containing 18, 16, and 14\% CP respectively with $3000 \mathrm{Kcal} / \mathrm{kg} \mathrm{ME}$ and adequately supplemented with required vitamins, minerals and amino acids. The treatments were: diet without brewer's dried grain -T1 (control diet), diet substituted with 10\% brewer's dried grain-T2, diet substituted with $20 \%$ brewer's dried grain-T3, diet substituted with $30 \%$ brewer's dried grain-T4 and diet substituted with $35 \%$ brewer's dried grain-T5. Twenty weaned piglets having 7.37 to $7.94 \mathrm{~kg}$ live weight were housed in individual pens. Five piglets were randomly assigned to the five treatments following a randomized complete block design (RCBD) considering each individual as a replication. Fortnightly live weight, daily feed consumption, income over feed and pig cost, and different meat traits of pigs were recorded. The effect of replacing formulated diets with various level of brewer's dried grains on body weight gain was significant $(p<0.01)$ with higher level of substitution resulting lower live-weight at the end of each of starter, grower and finisher diet period. The average body weight of piglets substituted with $35 \% \mathrm{BDG}(27.00 \mathrm{~kg})$ and $30 \% \mathrm{BDG}(39.75 \mathrm{~kg})$ were significantly lower $(\mathrm{p}<0.01)$ compared to the weight of piglets receiving $0 \%(65.75 \mathrm{~kg}), 10 \%(64.25 \mathrm{~kg})$ and $20 \%(60.25 \mathrm{~kg}) \mathrm{BDG}$ replaced diets at the end of 3 months experimental period. A significant reduction $(\mathrm{P}<0.01)$ in average daily feed consumption were also recorded with increasing level of BDG in the diet. Better feed conversion ratio (FCR) was observed in $\mathrm{T} 2$ at early period which at finisher stage T3 diet resulted significantly better FCR which was at par with T1 and T2 diet fed group. However, T5 diet resulted the poorest feed conversion ratio of 5.26, 4.92 and 5.87 for starter, grower and finisher respectively. There was reduction in feed cost with different levels of BDG substitution in diet of pig. Highest income (in per cent) over expenditure (109.01\%) was found in T2 followed by T1, T3, and T4. Lowest income over expenditure (-8.2\%) was found in T5. Highest dressing percent (71.87\%) was recorded in T1 and lowest (70\%) in T5 diet fed group. Inclusion of $10-20 \%$ BDG seems most acceptable level of substitution of SBM. However, this result needs to be verified under farmer's management condition before recommendation.
\end{abstract}

Key words: brewer's dried grains, swine performance

\section{Introduction}

Brewers' dried grain (BDG) is a solid waste from the brewery industries. It is available and cheap but difficult to dry to low moisture content for easy storage and use, especially during the wet seasons. There is wide variability in the proximate composition of BDG depending on the brewery that produced it. Feed accounts for about $65-70 \%$ of the cost of producing market-weight swine. Through the years, efforts have been made to optimize feed efficiency so that feed costs might be reduced. Such efforts depend on knowledge of nutrients availability in feed ingredients and the requirements of the pig for those nutrients for various physiological states. With increasing price of feed ingredients and their scarcity, intensive and continuous efforts are being made to seek agroindustrial by-products so that the cost is reduced without considerable effects on their performance. The aim of this study was to find out economic use of BDG in the diet of swine.

\section{Materials and Methods}

An experiment was conducted from October $18^{\text {th }} 2006$ to $18^{\text {th }}$ January 2007, at IAAS Livestock Farm, Rampur, Chitwan. Twenty weaned crossbred (Landrace $\mathrm{x}$ Yorkshire) piglets of same age, weighing about $5 \mathrm{~kg}$ were purchased from local farmers two weeks prior to 
the start of the actual experiment. Starter (45 to 75- daysold pig), grower (76 to 105- days- old pig), and finisher (106 to 135-days- old pig) diets were formulated containing 18, 16, and 14\%, CP respectively. These diets were isocaloric containing $3000 \mathrm{Kcal} / \mathrm{kg}$, ME and adequately supplemented with required vitamins, minerals and amino acids. The treatments were: diet without brewer's dried grain (WBDG) (Control Diet=T1), diet substituted with $10 \%$ brewer's dried grain $(10 \% \mathrm{BDG}=\mathrm{T} 2)$, diet substituted with $20 \%$ brewer's dried grain $(20 \% \mathrm{BDG}=\mathrm{T} 3)$, diet substituted with $30 \%$ brewer's dried grain $(30 \% \mathrm{BDG}=\mathrm{T} 4)$ and diet substituted with $35 \%$ brewer's dried grain $(35 \%$ $\mathrm{BDG}=\mathrm{T} 5$ ). Twenty weaned piglets of approximately $7.5 \mathrm{~kg}$ body weight were housed in individual pens.
Five piglets were randomly assigned to five treatments following a randomized complete block design (RCBD) with four replications. Average daily gain (ADG), average daily feed consumption (ADFC), Feed conversion ratio (FCR), Carcass traits, and income over feed and pig cost were calculated. All the data collected were subjected to statistical analysis using the Microsoft Excel, and MSTAT-C version 1.3 Michigan University (1975). Tests of significance among treatments means were performed using the least significant difference (LSD) at $5 \%$. The ingredients composition and calculated nutrients contents of swine starter, grower and finisher diets substituted with different levels of BDG is presented in Table 1, 2 and 3 respectively.

Table 1. Feed ingredients and nutrient contents of swine starter diets substituted with different levels of BDG

\begin{tabular}{l|l|l|l|l|l}
\hline Ingredients & WBDG & $10 \% \mathrm{BDG}$ & $20 \% \mathrm{BDG}$ & $30 \% \mathrm{BDG}$ & $35 \% \mathrm{BDG}$ \\
\hline Maize & 47.82 & 50.62 & 58.06 & 49.75 & 45.72 \\
Rice polish & 12.00 & 10.00 & 0.10 & 0.05 & 0.05 \\
Soybean meal & 20.00 & 15.00 & 10.00 & 5.00 & 0.00 \\
Til cake & 4.30 & 5.50 & 6.50 & 7.00 & 9.60 \\
Bone meal & 0.50 & 0.50 & 1.60 & 1.60 & 1.60 \\
BDG & 0.00 & 10.00 & 20.00 & 30.00 & 35.00 \\
DOC & 12.00 & 5.00 & 0.10 & 0.05 & 0.00 \\
L/stone & 1.20 & 1.20 & 1.00 & 1.00 & 1.00 \\
Molasses & 1.00 & 1.00 & 0.10 & 0.05 & 0.00 \\
Soy oil & 0.00 & 0.00 & 1.20 & 4.00 & 5.50 \\
Lysine & 0.00 & 0.00 & 0.16 & 0.31 & 0.34 \\
Methionine & 0.18 & 0.18 & 0.18 & 0.19 & 0.19 \\
Salt & 0.50 & 0.50 & 0.50 & 0.50 & 0.50 \\
Feed supplements & 0.50 & 0.50 & 0.50 & 0.50 & 0.50 \\
Total & 100.00 & 100.00 & 100.00 & 100.00 & 100.00 \\
\hline
\end{tabular}


T.B. Rijal et al./Economic Use of Brewer's....

Table 2. Feed ingredient and nutrient contents of swine grower's diet substituted with different levels of BDG

\begin{tabular}{|c|c|c|c|c|c|}
\hline Ingredients & WBDG & $10 \% \mathrm{BDG}$ & $20 \% \mathrm{BDG}$ & $30 \% \mathrm{BDG}$ & $35 \% \mathrm{BDG}$ \\
\hline Maize & 54.96 & 58.15 & 66.25 & 56.96 & 53.43 \\
\hline Rice polish & 6.50 & 5.00 & 0.30 & 0.00 & 0.10 \\
\hline Soybean meal & 20.00 & 15.00 & 10.00 & 5.00 & 0.00 \\
\hline Tile cake & 1.20 & 0.40 & 0.60 & 1.00 & 3.60 \\
\hline Bone meal & 0.50 & 0.50 & 1.20 & 1.50 & 1.40 \\
\hline BDG & 0.00 & 10.00 & 20.00 & 30.00 & 35.00 \\
\hline DOC & 6.50 & 5.50 & 0.00 & 0.50 & 0.10 \\
\hline L/stone & 1.20 & 1.20 & 0.50 & 0.50 & 0.40 \\
\hline Molasses & 8.00 & 3.10 & 0.00 & 0.05 & 0.00 \\
\hline Soy oil & 0.00 & 0.00 & 0.00 & 3.20 & 4.50 \\
\hline Lysine & 0.00 & 0.00 & 0.00 & 0.14 & 0.31 \\
\hline Methionine & 0.14 & 0.15 & 0.15 & 0.15 & 0.16 \\
\hline Salt & 0.50 & 0.50 & 0.50 & 0.50 & 0.50 \\
\hline Feed supplements & 0.50 & 0.50 & 0.50 & 0.50 & 0.50 \\
\hline Total & 100.00 & 100.00 & 100.00 & 100.00 & 100.00 \\
\hline \multicolumn{6}{|c|}{ Nutrient content } \\
\hline ME kcal/kg & 3049.94 & 3008.26 & 3000.22 & 3000.30 & 3001.42 \\
\hline $\mathrm{CP} \%$ & 16.00 & 16.00 & 16.02 & 16.04 & 16.00 \\
\hline Lysine $\%$ & 1.05 & 0.90 & 0.76 & 0.75 & 0.75 \\
\hline Methionine \% & 0.41 & 0.41 & 0.41 & 0.41 & 0.41 \\
\hline $\mathrm{Ca} \%$ & 0.70 & 0.69 & 0.61 & 0.71 & 0.70 \\
\hline $\mathrm{P} \%$ & 0.50 & 0.53 & 0.50 & 0.54 & 0.54 \\
\hline
\end{tabular}

Table 3. Feed ingredients and nutrient contents of swine finisher diets substituted with different levels of BDG

\begin{tabular}{|c|c|c|c|c|c|}
\hline Ingredients & WBDG & $10 \% \mathrm{BDG}$ & $20 \% \mathrm{BDG}$ & $30 \% \mathrm{BDG}$ & $35 \% \mathrm{BDG}$ \\
\hline Maize & 54.37 & 59.38 & 70.64 & 63.21 & 57.51 \\
\hline Rice polish & 9.00 & 10.00 & 0.50 & 0.10 & 0.10 \\
\hline Soybean meal & 15.00 & 10.00 & 5.50 & 0.80 & 0.00 \\
\hline Tile cake & 0.00 & 0.00 & 0.00 & 0.00 & 0.00 \\
\hline Bone meal & 0.30 & 0.50 & 0.50 & 0.50 & 0.50 \\
\hline BDG & 0.00 & 10.00 & 20.00 & 30.00 & 35.00 \\
\hline DOC & 10.00 & 3.00 & 0.00 & 0.10 & 0.10 \\
\hline $\mathrm{L} /$ stone & 1.20 & 1.00 & 1.20 & 1.10 & 1.20 \\
\hline Molasses & 9.00 & 5.00 & 0.50 & 0.20 & 0.10 \\
\hline Soy oil & 0.00 & 0.00 & 0.00 & 2.70 & 4.20 \\
\hline Lysine & 0.00 & 0.00 & 0.04 & 0.17 & 0.18 \\
\hline Methionine & 0.13 & 0.12 & 0.12 & 0.12 & 0.11 \\
\hline Salt & 0.50 & 0.50 & 0.50 & 0.50 & 0.50 \\
\hline Feed supplements & 0.50 & 0.50 & 0.50 & 0.50 & 0.50 \\
\hline Total & 100.00 & 100.00 & 100.00 & 100.00 & 100.00 \\
\hline \multicolumn{6}{|c|}{ Nutrient contents } \\
\hline$\overline{\mathrm{ME} \mathrm{kcal} / \mathrm{kg}}$ & 3003.25 & 3005.30 & 3002.53 & 3003.10 & 3001.60 \\
\hline $\mathrm{CP} \%$ & 14.00 & 14.02 & 14.06 & 14.06 & 14.58 \\
\hline Lysine \% & 0.82 & 0.70 & 0.56 & 0.60 & 0.60 \\
\hline Methionine \% & 0.21 & 0.34 & 0.34 & 0.34 & 0.34 \\
\hline $\mathrm{Ca} \%$ & 0.62 & 0.59 & 0.67 & 0.64 & 0.69 \\
\hline $\mathrm{P} \%$ & 0.58 & 0.52 & 0.40 & 0.40 & 0.40 \\
\hline
\end{tabular}




\section{Results and Discussion \\ Live weight}

The average cumulative live weight $(\mathrm{kg})$ of crossbred (Landrace $\mathrm{x}$ Yorkshire) swine fed diets containing different levels of BDG is presented in Table 4. During the starter diet period (1 month feeding), the piglets fed diet without any BDG (T1) attained the highest body weight $(19.97 \mathrm{~kg})$ followed by diet substituted with 20\%BDG-T3(19.68kg) and 10\%BDG substituted (T2) diet (18.75kg). Substituting more than 20\%BDG significantly $(p<0.01)$ reduced the body weight at the end of finisher diet period with body weight of only $15.43 \mathrm{~kg}$ (T4) and $11.62 \mathrm{~kg}(\mathrm{~T} 5)$. Similar trend was also observed during growers' ( $3^{\text {rd }}$ and $4^{\text {th }}$ fortnight) and finisher diet period ( $5^{\text {th }}$ and $6^{\text {th }}$ fortnight). At the end of 3 months experimental period, the piglets in diet T2 $(10 \%$ BDG substituted diet) attained $64.25 \mathrm{~kg}$ body weight which was at par with the body weight of piglets $(65.75 \mathrm{~kg})$ receiving control (WBDG-T1) diet.

Table 4. Average fortnightly cumulative live weight (kg) of crossbred (Landrace x Yorkshire) swine fed diets containing different levels of BDG

\begin{tabular}{l|l|l|l|l|l|l|l}
\hline Treatments & \multicolumn{6}{l}{ Fortnightly live weight change } \\
\hline & Initial & $1^{\text {st }}$ & $2^{\text {nd }}$ & $3^{\text {rd }}$ & $4^{\text {th }}$ & $5^{\text {th }}$ & 6 th \\
T1 (WBDG) & 7.94 & $13.38^{\text {ab }}$ & $19.97^{\mathrm{a}}$ & $28.25^{\mathrm{a}}$ & $41.25^{\mathrm{a}}$ & $51.25^{\mathrm{a}}$ & $65.75^{\mathrm{a}}$ \\
T2 $(10 \% \mathrm{BDG})$ & 7.54 & $13.69^{\mathrm{a}}$ & $18.75^{\mathrm{a}}$ & $27.25^{\mathrm{a}}$ & $40.00^{\mathrm{a}}$ & $50.00^{\mathrm{a}}$ & $64.25^{\mathrm{ab}}$ \\
T3(20\%BDG) & 7.54 & $14.73^{\mathrm{a}}$ & $19.68^{\mathrm{a}}$ & $28.25^{\mathrm{a}}$ & $37.50^{\mathrm{a}}$ & $49.25^{\mathrm{a}}$ & $60.25^{\mathrm{b}}$ \\
T4 $(30 \% \mathrm{BDG})$ & 7.37 & $11.28^{\mathrm{bc}}$ & $15.43^{\mathrm{b}}$ & $21.25^{\mathrm{b}}$ & $26.25^{\mathrm{b}}$ & $32.50^{\mathrm{b}}$ & $39.75^{\mathrm{c}}$ \\
T5 (35\% BDG) & 7.48 & $9.23^{\mathrm{c}}$ & $11.62^{\mathrm{c}}$ & $14.50^{\mathrm{c}}$ & $18.00^{\mathrm{c}}$ & $22.50^{\mathrm{c}}$ & $27.00^{\mathrm{d}}$ \\
Probability & 0.99 & 0.06 & $0.00^{* *}$ & $0.00^{* *}$ & $0.00^{* *}$ & $0.00^{* *}$ & $0.00^{* *}$ \\
CV\% & 18.99 & 15.19 & 14.22 & 15.52 & 12.77 & 10.89 & 7.19 \\
LSD & $\mathrm{ns}$ & 2.159 & 4.827 & 7.275 & 8.055 & 8.776 & 7.188 \\
\hline
\end{tabular}

Means within columns having different superscripts are significant at $\mathrm{P}<0.01$

Decreasing trend of live weight from $4^{\text {th }}$ fortnight to $6^{\text {th }}$ fortnight study period was observed with increasing levels of BDG. However, control diet, $10 \%$ BDG and $20 \%$ BDG substituted diet from $1^{\text {st }}$ to $6^{\text {th }}$ fortnight did not vary significantly $(\mathrm{p}>0.05)$. However, which was differed significantly $(\mathrm{p}<0.05)$ with the values observed in $\mathrm{T} 5$ diet. The results of this study are in line with those of Yaakugh and Tegbe (1990) who also recorded depressed growth performance of grower pigs at highest inclusion level of 30\% BDG. Babatunde et al. (1975) and Yaakugh and Tegbe, (1990) indicated that grower pigs fed at $15 \% \mathrm{BDG}$ and $35 \% \mathrm{BDG}$ had the same growth rate and feed conversion ratio as compare to control diet respectively. Some of the reports indicated that high BDG levels in pigs' diets depressed feed intake and growth rate (Kornegay 1973), which was attributed to high dietary crude fibre intake (Yaakugh and Tegbe 1990). Yaakugh and Tegbe (1990) also reported that the bulky nature of BDG diets might have adversely affected the digestibility, as well as the availability of amino acids and other nutrients of pigs.

\section{Daily feed consumption}

Average daily feed consumption $(\mathrm{kg})$ of cross bred (Landrace $\mathrm{x}$ Yorkshire) swine fed diets containing different levels of brewer's dried grain is presented in Table 5. Accordingly, average daily feed consumption $(\mathrm{kg})$ did not differ significantly among the different treatments during first fortnight of feeding trial. However, the daily feed consumption differed significantly $(\mathrm{P}<0.01)$ during $2^{\text {nd }}$ fortnight among treatment groups with highest daily feed consumption of $1.24 \mathrm{~kg}$ and lowest of $0.77 \mathrm{~kg}$ in control diet and diet substituted with $35 \%$ BDG respectively. In rest of the experimental period, daily feed consumption among the piglets receiving $\mathrm{T} 1, \mathrm{~T} 2$ and $\mathrm{T} 3$ were similar but were significantly $(\mathrm{p}<0.01)$ higher than those in the piglets 
groups receiving $\mathrm{T} 4$ and $\mathrm{T} 5$ diets. The average daily feed consumption during the whole experimental period was highest in piglets receiving $\mathrm{T} 1 \operatorname{diet}(1.86 \mathrm{~kg})$ and lowest in piglets receiving T5 diet $(1.11 \mathrm{~kg})$. Yaakugh and Tegbe (1990) also reported that the bulky nature of BDG diets may have adversely affected the digestibility, as well as the availability of amino acids and other nutrients of pigs. This might be the reason in the present study also where increasing level of bulky BDG had reduced the total feed consumption.

Table 5. Average daily feed consumption (kg) of crossbred (Landrace $x$ Yorkshire) swine fed diets containing different levels of Brewer's dried grain at IAAS, Livestock Farm, Rampur Chitwan 2006/07

\begin{tabular}{|c|c|c|c|c|c|c|c|}
\hline \multirow[t]{2}{*}{ Treatments } & \multicolumn{7}{|c|}{ Average daily feed consumption in different fortnight } \\
\hline & $1^{\mathrm{st}}$ & $2^{\text {nd }}$ & $3^{\text {rd }}$ & $4^{\text {th }}$ & $5^{\text {th }}$ & 6th & Overall mean \\
\hline T1 (WBDG) & 0.80 & $1.24^{\mathrm{a}}$ & $1.52^{\mathrm{a}}$ & $2.30^{\mathrm{a}}$ & $2.44^{\mathrm{a}}$ & $2.90^{\mathrm{a}}$ & 1.86 \\
\hline $\mathrm{T} 2(10 \% \mathrm{BDG})$ & 0.67 & $0.91^{\mathrm{bc}}$ & $1.24^{\mathrm{ab}}$ & $1.78^{\mathrm{b}}$ & $2.41^{\mathrm{a}}$ & $2.80^{\mathrm{a}}$ & 1.63 \\
\hline $\mathrm{T} 3(20 \% \mathrm{BDG})$ & 0.71 & $1.03^{\mathrm{ab}}$ & $1.29^{\mathrm{ab}}$ & $1.78^{\mathrm{b}}$ & $2.10^{\mathrm{b}}$ & $2.21^{\mathrm{b}}$ & 1.52 \\
\hline $\mathrm{T} 4(30 \% \mathrm{BDG})$ & 0.67 & $1.06^{\mathrm{ab}}$ & $1.21^{\mathrm{b}}$ & $1.59^{\mathrm{c}}$ & $1.92^{\mathrm{c}}$ & $1.98^{\mathrm{c}}$ & 1.40 \\
\hline T5 (35\% BDG) & 0.61 & $0.77^{\mathrm{c}}$ & $0.78^{\mathrm{c}}$ & $1.15^{\mathrm{d}}$ & $1.50^{\mathrm{d}}$ & $1.87^{\mathrm{c}}$ & 1.11 \\
\hline Probability & 0.13 & $0.01 * *$ & $0.00 * *$ & $0.00 * *$ & $0.00 * *$ & $0.00 * *$ & \\
\hline $\mathrm{CV} \%$ & 13.28 & 15.82 & 15.36 & 5.13 & 3.47 & 3.98 & \\
\hline LSD & $\mathrm{ns}$ & 0.24 & 0.28 & 0.13 & 0.10 & 0.14 & \\
\hline
\end{tabular}

Means within columns having different superscripts are significant at $\mathrm{P}<0.05$

\section{Income over feed and pig cost}

Income over feed and piglet cost of crossbred swine fed diets containing different levels of BDG is presented in Table 6. In general there was reduction in all types of feed cost with up to $20 \%$ BDG substitution. However, above $20 \%$ substitution, an increment per $\mathrm{kg}$ feed cost was observed. It was because of the fact that an increment in the level of substitution of BDG above $20 \%$ there was less energy content than the required. To fulfill the energy level, higher amount of soybean oil was used costing approximately Rs. 75/litre which increased the price of per kg diet resulting into higher production cost, consequently affecting in the gross as well as net income. Highest gross income (Rs. 5198.0) as well as net income (Rs. 2687.34) resulted from control diet (T1) followed by T2, T3 and T4. Lowest gross income (Rs. 2079) and net income (Rs. -191.09) was recorded in diet fed with $35 \%$ BDG substitution for SBM.
However, maximum income (109\%) over expenditure was observed in $10 \%$ BDG (T2) followed by control diet (T1), 20\% BDG (T3) and 30\% BDG (T4) and minimum (-8.42\%) was obtained from 35\% BDG (T5). It was observed that the lower total feed cost of $30 \%$ BDG and 35\% BDG diet did not result increased gross income from sale of meat and in net income as well as percent income over expenditure. This result is in agreement with the result of Amaefule et al. (2006). They have observed that the lower total feed cost of $40 \%$ BDG diet did not result in lower feed cost per $\mathrm{kg}$ weight gain and increased gross margin, suggesting that there might not be increased financial benefit as a result of increasing the inclusion level of BDG in the diet above $30 \%$. Therefore, from the economic point of view the optimum inclusion level of BDG in pig diet is $10-20 \%$, since cost minimization and gross income optimization is observed at these levels. 
Table 6. Income over feed and piglet cost (IOFPC) of cross bred (Landrace $x$ Yorkshire) swine fed diets containing different levels of Brewer's dried grain

\begin{tabular}{|c|c|c|c|c|c|c|c|c|c|c|}
\hline Treatments & \multicolumn{3}{|c|}{ Cost of ration $(\mathrm{Rs} / \mathrm{kg})$} & $\mathrm{TFC}(\mathrm{kg})$ & $\begin{array}{l}\text { TFPMLC } \\
\text { (Rs) }\end{array}$ & $\mathrm{LW}(\mathrm{kg})$ & \multicolumn{2}{|c|}{\begin{tabular}{l|l} 
CPM Rs/ & GISM @ \\
kg & Rs110/kg
\end{tabular}} & NI (Rs) & $\% \mathrm{IOE}$ \\
\hline T1 (WBDG) & 13.68 & 13.61 & 12.97 & 168.32 & 2510.66 & 65.75 & 53.13 & 5198.00 & 2687.34 & 107.04 \\
\hline $\mathrm{T} 2(10 \% \mathrm{BDG})$ & 12.70 & 12.54 & 12.07 & 147.50 & 2404.48 & 64.25 & 52.63 & 5025.70 & 2621.22 & 109.01 \\
\hline T3 (20\% BDG) & 12.92 & 11.78 & 11.39 & 137.00 & 2354.76 & 60.25 & 54.93 & 4715.47 & 2360.70 & 100.25 \\
\hline $\mathrm{T} 4(30 \% \mathrm{BDG})$ & 13.55 & 12.57 & 11.36 & 126.50 & 2336.87 & 39.75 & 83.12 & 3092.67 & 755.80 & 32.34 \\
\hline T5 (35\% BDG) & 13.73 & 12.92 & 12.21 & 100.50 & 2270.09 & 27.00 & 120.11 & 2079.00 & -191.09 & -8.42 \\
\hline
\end{tabular}

Means within columns having different superscripts are significant at $\mathrm{P}<0.05$

\section{Meat traits}

Percentage sharing of different carcass traits of crossbred swine fed diets containing different levels of brewer's dried grain is presented in Table 7. Accordingly highest dressing percent $(71.87 \%)$ was recorded with control diet (T1) and lowest (70\%) with diet substituted $35 \%$ brewer's dried grain (T5). Higher inedible meat (18.83\%) was observed in $\mathrm{T} 4$ and lower $(17.17 \%)$ in T3. However, highest (11.67\%) edible meat was recorded in $\mathrm{T} 3$ and lowest $(10.44 \%)$ in $\mathrm{T} 4$.
Percentage sharing of different whole sale/retail cuts of carcass against live weight basis of crossbred swine fed diets containing different levels of BDG is presented in Table 8. Accordingly, percentage sharing of different carcass traits including heart, liver, spleen, kidney, lungs, head, hairs + blood were similar in all treatment groups. Percentage sharing of different whole sale/retail cuts of carcass including Ham, Loin, Boston Shoulder, Picnic Shoulder, Belly clear plate etc were also similar in all treatments groups.

Table 7. Meat traits dressing percent of crossbred swine fed diets containing different levels of Brewer's dried grain at IAAS, Livestock Farm, Rampur, Chitwan, 2006

\begin{tabular}{|c|c|c|c|c|c|c|c|c|c|c|}
\hline \multirow{2}{*}{$\begin{array}{l}\text { Description } \\
\text { ofdifferent cut } \\
\text { parts }\end{array}$} & \multicolumn{2}{|c|}{$\mathrm{T} 1$} & \multicolumn{2}{|c|}{$\mathrm{T} 2$} & \multicolumn{2}{|c|}{$\mathrm{T} 3$} & \multicolumn{2}{|c|}{$\mathrm{T} 4$} & \multicolumn{2}{|c|}{$\mathrm{T} 5$} \\
\hline & $\begin{array}{l}\text { Weight } \\
(\mathrm{kg})\end{array}$ & $\%$ & $\begin{array}{l}\text { Weight } \\
(\mathrm{kg})\end{array}$ & $\%$ & $\begin{array}{l}\text { Weight } \\
(\mathrm{kg})\end{array}$ & $\%$ & $\begin{array}{l}\text { Weight } \\
(\mathrm{kg})\end{array}$ & $\%$ & $\begin{array}{l}\text { Weight } \\
(\mathrm{kg})\end{array}$ & $\%$ \\
\hline Live weight & 62 & - & 45 & - & 52 & - & 41 & - & 25 & \\
\hline Dressed weight & 44.56 & 71.87 & 32.00 & 71.11 & 37.00 & 71.15 & 29.00 & 70.73 & 17.50 & 70.00 \\
\hline Inedible & 10.81 & 17.44 & 7.90 & 17.55 & 8.93 & 17.17 & 7.72 & 18.83 & 4.61 & 18.44 \\
\hline Visceral weight* & 9.65 & 15.50 & 6.90 & 15.23 & 7.83 & 15.00 & 6.72 & 16.40 & 4.00 & 16.00 \\
\hline Hair + Blood & 1.16 & 1.90 & 1.00 & 2.25 & 1.10 & 2.10 & 1.00 & 2.40 & 0.61 & 2.44 \\
\hline Edible & 6.63 & 10.69 & 5.10 & 11.33 & 6.07 & 11.67 & 4.28 & 10.44 & 2.89 & 11.56 \\
\hline Heart & 0.34 & 0.54 & 0.20 & 0.45 & 0.20 & 0.50 & 0.20 & 0.54 & 0.10 & 0.40 \\
\hline Liver & 1.65 & 2.60 & 1.00 & 2.25 & 1.45 & 2.80 & 0.80 & 1.95 & 0.51 & 2.04 \\
\hline Spleen & 0.15 & 0.29 & 0.75 & 1.66 & 0.12 & 0.25 & 0.10 & 0.25 & 0.06 & 0.24 \\
\hline Kidney & 0.44 & 0.70 & 0.20 & 0.45 & 0.25 & 0.50 & 0.15 & 0.35 & 0.10 & 0.40 \\
\hline Lungs & 0.55 & 0.90 & 0.65 & 1.45 & 0.55 & 1.00 & 0.33 & 0.80 & 0.12 & 0.48 \\
\hline Head & 3.50 & 5.70 & 2.30 & 5.15 & 3.50 & 6.70 & 2.70 & 6.58 & 2.00 & 8.00 \\
\hline Left half & 22.26 & 35.90 & 16.00 & 35.56 & 18.00 & 34.62 & 14.00 & 34.15 & 8.50 & 34.00 \\
\hline Right Half & 22.30 & 35.97 & 16.00 & 35.55 & 19.00 & 36.54 & 15.00 & 36.58 & 9.00 & 36.00 \\
\hline Total & 62.00 & 100.00 & 45.00 & 100.00 & 52.00 & 100.00 & 41.00 & 100.00 & 25.00 & 100.00 \\
\hline
\end{tabular}

*(Intestine full + Stomach full) 
Table 8. Meat traits and dressed weight of swine fed diets containing different levels of brewer's dried grain at IAAS, Livestock Farm, Rampur, Chitwan, 2006

\begin{tabular}{|c|c|c|c|c|c|c|c|c|c|c|}
\hline \multirow[t]{2}{*}{ Meat traits } & \multicolumn{2}{|l|}{$\mathrm{T} 1$} & \multicolumn{2}{|c|}{$\mathrm{T} 2$} & \multicolumn{2}{|c|}{$\mathrm{T} 3$} & \multicolumn{2}{|c|}{$\mathrm{T} 4$} & \multirow[b]{2}{*}{$\begin{array}{l}\text { Weight } \\
(\mathrm{kg})\end{array}$} & \multirow[b]{2}{*}{$\%$} \\
\hline & $\begin{array}{l}\text { Weight } \\
(\mathrm{kg})\end{array}$ & $\%$ & $\begin{array}{l}\text { Weight } \\
(\mathrm{kg})\end{array}$ & $\%$ & $\begin{array}{l}\text { Weight } \\
(\mathrm{kg})\end{array}$ & $\%$ & $\begin{array}{l}\text { Weight } \\
\text { (kg) }\end{array}$ & $\%$ & & \\
\hline Ham & 9.36 & 15.13 & 6.50 & 14.45 & 7.50 & 14.35 & 6.20 & 15.00 & 3.60 & 14.40 \\
\hline Loin & 8.50 & 13.74 & 6.00 & 13.35 & 6.50 & 12.50 & 5.40 & 13.20 & 3.20 & 12.80 \\
\hline Boston Shoulder & 2.80 & 4.50 & 2.00 & 4.45 & 2.50 & 4.80 & 2.00 & 4.80 & 1.30 & 5.20 \\
\hline Picnic Shoulder & 4.00 & 6.60 & 3.00 & 6.71 & 3.20 & 6.20 & 2.40 & 5.60 & 1.50 & 6.00 \\
\hline Belly & 7.50 & 12.00 & 5.40 & 12.00 & 6.50 & 12.50 & 4.80 & 12.50 & 3.00 & 12.00 \\
\hline Spare ribs & 1.50 & 2.60 & 1.10 & 2.45 & 1.50 & 2.90 & 1.00 & 2.30 & 0.60 & 2.40 \\
\hline Jowl & 1.30 & 2.00 & 1.00 & 2.25 & 1.20 & 2.30 & 0.90 & 2.20 & 0.50 & 2.00 \\
\hline Feet, Tail, Neck bone & 2.70 & 4.30 & 2.00 & 4.45 & 2.30 & 4.40 & 1.80 & 4.30 & 1.00 & 4.00 \\
\hline Fat back, Clear plate, Fat trim & 5.00 & 8.00 & 3.50 & 7.65 & 4.30 & 8.30 & 3.20 & 7.73 & 2.00 & 8.00 \\
\hline Lean trim & 1.90 & 3.00 & 1.50 & 3.35 & 1.50 & 2.90 & 1.30 & 3.10 & 0.80 & 3.20 \\
\hline Total & 44.56 & 71.87 & 32.00 & 71.11 & 37.00 & 71.15 & 29.00 & 70.73 & 17.50 & 70.00 \\
\hline
\end{tabular}

The results obtained from the study indicated that up to $20 \%$ BDG inclusion could be the optimum substitutional level from all respect. Hence, farmers/ pig growers can utilize BDG in place of SBM up to $20 \%$ without jeopardizing the overall performance of the swine production. However, this result needs to be verified under farmer's management condition before recommendation.

\section{Acknowledgment}

The authors wish deep sense of gratitude to the Director of Research, Dean of Institute of Agriculture and Animal Sciences, and all those who directly or indirectly helped in this study.

\section{References}

Amaefule, K.U., S.O. Okechukwu, S.N. Ukachukwu, F.Cc Okoye and O.C. Onwudike. 2006. Digestibility and nutrient utilization of pigs fed graded levels of brewers' dried grain based diets. Livestock Research for Rural Development 18 (1): from http://www.irrd.org/Irrd18/17 amae 18005. htm

Babatunde, G.M., B.L. Fetuga, V.A. Oyenuga and A. Ayoade. 1975. The effect of graded levels of brewers' dried grain and maize cobs in the diets of pigs on their performance characteristics and carcass quality. Nigerian Journal of Animal Production 2: 119-133.

Kornegay, E.T. 1973. Digestible and metabolizable energy and protein utilization values of brewers' dried by-products for swine. Journal of Animal Science 37: 479-483.

MSTAT-C. 1975. Basic version 1.3 Michigan STATE University, USA.

Yaakugh, I.D.I. and T.S.B. Tegbe 1990. Performance and carcass characteristics of grower and finisher pigs fed diets containing brewers' dry grain. Nigerian Agricultural Journal 24: 31-40. 
Nepal Journal of Science and Technology 10 (2009) 